\title{
Impact of Decrease in Supply of Land for Domestic Use in North Cyprus: Computerized General Equilibrium (CGE) Model Approach
}

\author{
Ph.D. Candidate Nuru Giritli (Eastern Mediterranean University, Cyprus) \\ Assoc. Prof. Dr. Sevin Uğural (Eastern Mediterranean University, Cyprus)
}

\begin{abstract}
Cyprus Island has been divided into two parts since 1974. In April 2003 crossing the Green Line across the borders became possible and both parts of the Island benefited from this; firstly due to resulted domestic tourism in both sides and secondly from new employment opportunities mainly for Turkish Cypriots in South. Besides that, positive expectations over the Cyprus problem accelerated the expenditures in both sides. In the North, demand for land and new dwellings increased, pushing prices upward. Demand for land and a new property by foreigners is busted in recent years. The UK, Israel, Russia and some other countries started to buy land in the North Cyprus by securing resources to their businessmen especially in the areas of Komi Kepir, Kalogrea, Akanthou, Karpass, Risokarpaso, Yialousa and Livera. Such increase in demand by foreigners decreased the supply of land to domestic use. This has many implications on North Cyprus economy which is very small with limited resources in production. In this study, 4- factor, 13-industry a single country general equilibrium model is used to investigate the changes in income, employment, prices, output and inputs required for production resulted from this supply shock. Results show that, under fixed capital and flexible labor market, $10 \%$ reduction in land supply increased the value of land by $108.8 \%$, income increased by $2.04 \%$ and prices of skilled labor and capital increased by $1.028 \%$ and $1.020 \%$ respectively and due to the reduction of land supply, output decreased by $1.53 \%$.
\end{abstract}

JEL codes: C63, C68

\section{Introduction}

North Cyprus economy is a small island economy hence, it faces high international transportation cost; indirect taxes and duties are also relatively high. Hence imported goods used, manufacture and consumption goods are costly. Significant trade barriers do exist primarily due to the unrecognized status of the North Cyprus as a sovereign state. However this unstable political environment makes the North Cyprus economy highly vulnerable to external shocks. One of the characteristics of the country's economy is that, the Central Bank does not function properly to control money supply to set the appropriate interest rates. The economy therefore lacks the monetary policy tools to stabilize the economy.

In this study we created a CGE model for North Cyprus economy with special features which have not been tried before but necessitated by the nature of the economy. Our general equilibrium model is built to reflect the features of the labor and product market conditions and state of the government. With the nested CES production function we attempt to capture the productivity of skilled labor versus unskilled labor when external shocks are inquired. Therefore, in our analysis, we consider not only the involvement of skilled and unskilled labor but also their productivity and their use with the other resources. This model therefore is constructed with four "distinct" factors of production, skilled and unskilled labor, mobile capital and land, and it will enable us to examine the impact of the mobility of factors within industries and between countries. Besides, modeling North Cyprus economy's characteristics, such a CGE model can be very useful for the developing countries where mobility of factors are taken into account, to consider possible / potential externalities arising from the factor mobility. In this paper, characteristics of the North Cyprus labor market are reflected to take into account the international mobility of both its skilled and unskilled labor forces. There exist large numbers of skilled Turkish Cypriot workers in the North that have no restriction towards moving to other countries in the EU. Also, part of the labor force of skilled workers move with little restriction between Turkey and North Cyprus.

In this paper, our simulations will address combine effects of the external shock of decrease in supply of land for domestic use in North Cyprus. The reason for studying external shock on land use in CGE framework is motivated by the current developments in North Cyprus. Foreign demand for land increased the land prices dramatically affecting the factors of production, GDP, output and aggregate demand in North Cyprus. This paper gives brief information about the CGE models and their applications in literature. Then model and methodology of our model is explained. Last section shows the impact of land supply reduction on income, output, factor prices and factors employed in production process in North Cyprus. 


\section{Literature Survey}

A CGE model is an economy-wide framework and there exists, various types of models such as "singlecountry general equilibrium models and multi-national (regional) general equilibrium models which are conducted to examine several issues; impact of tax reforms, welfare effect of energy and environmental issues, natural resource policies, international trade and distributional impact of migration on host-and-sending countries. Most of the studies consider Cobb Douglas type production function, with 2 broad categories of factors of production when information on elasticity of substitution parameters are not known or hard to estimate because of data unavailability; However, CES production functions are used with more general specification that factors of production are aggregated into two broad categories (capital and labor) where this form allows substitution between labor and capital. Some models evolved in a way that, in addition to capital, labor is distinguished by skilled and unskilled sub-categories and these types of models necessitate using nested-CES production functions, and thus, it enables us to take complementary or substitution effects into account. A simple single-national general equilibrium model by Shoven and Whalley (1984) with 2-goods, 2-factors and 2consumers aimed to analyze potential changes of the US government taxation policies. Their production function is aggregated into 2 primary factors (capital and labor) and is represented by CES function to allow substitution between primary factors in use, which follows a cost minimization process. Shoven and Whalley thinks using hierarchical or nested CES functions add further complexity in structure therefore he uses aggregated 2 inputs in his model. The author excludes analysis of government and investors' demand decisions in his analysis and trade closure is taken exogenously in his model. Cardenete and Sancho (2003) developed a general equilibrium model with a regional perspective to evaluate the impact of national tax changes in one region in Spain. Williams (2003) contributes on the debate using three-region, three factor, and six-good multi-national computable general equilibrium model. The model was constructed as follows; for the one type of producer, capital is explicitly included in the nested CES type production function together with unskilled labor. Then for the second type of producer, again CES type production function is used where skilled labor and composite of unskilled labor and capital are used as inputs to the production function. Okkerse (2003), built a general equilibrium model to analyze the effects of migration in Belgium; the production function, investment and government's exogenous involvement was similar to William's way of constricting a model. The author also included trade closure in his model, using a CET (constant elasticity of transformation) function for the exported commodities and CES function with Armington assumption for the imported commodities.

\section{The Model and Methodology}

Mathematical formulation of the model consists of four building blocks - an institution block, represented by households, firms, government and by the rest of the world; a price block, a production-and-commodity block and finally a system constraint block. The data used for the construction of our CGE model is called a social accounting matrix (SAM) that specifies the aggregate factor endowments, the outputs by the 13-industry groups, factor usage by production activity and the input-output structure. Within the production and commodity block, there are four factors of production in this model; unskilled labor, capital, skilled labor (professionals and managers) and land, where the output is determined by a 3 level nested CES production function. Output consists of two parts. The first part is the value created by intermediate goods and services, used through consistent inputoutput coefficients and there is no substitution between the intermediate inputs used. The second part comes from the value added which is the value created by the factors of production. Here, substitution among the primary inputs is allowed. Unskilled labor $(\mathrm{L})$ and skilled labor $(\mathrm{H})$ are mobile with some constraints between the industries and capital $(\mathrm{K})$ is mobile both between industries and internationally. Land (R), including natural resources is fixed and immobile. To allow factor input substitution within each industry, a special 3-level nested CES production function is used. Preferences of the households represented by CES utility function are aggregated into two groups; tradable goods (industries 1-6) and services (industries 7-13). Although the CES function enables us to consider the elasticity of substitution between the commodities, it has some limitations. To overcome these problems two separate constrained utility maximizations are conducted to yield optimum values of consumption of the aggregated tradable goods and aggregated services that are then entered into the CES utility function. We call this formation of the CES utility function a "2-legged-nested CES utility function" In the institution block the firms make investment, the government buys goods and services for consumption and investment. These institutions are represented by a Cobb-Douglas utility function. Regarding the rest of the world, the imports are derived through a CES function implying the Armington assumption and exports through a CET function.

\subsection{Production}

This section consists of an explanation and algebraic formulation of production. The output consists of two parts; input use, coming from a Leontief production function and value added coming from a 3-level nested CES function. In the first nest of the production function, labor $(\mathrm{L})$ enters the production function together with capital $(\mathrm{K})$. Then they jointly enter the production function together with labor $(\mathrm{H})$ at the second nest of the 
production. This process allows unskilled labor substitution with the composite factors, in other words, labor (L) and capital (K) are complements with each other. This means; if capital inputs are complements in production with skilled labor then it will require more capital to go along with more skilled labor and thus, there will be a bigger scale effect. In North Cyprus, education level is high; and an upward trend of investing in human capital is one of the determinants of the skilled labor and, thus, wages of those is relatively high compare to the wages of unskilled labor. If wages of labor $(\mathrm{H})$ rise, we substitute away from labor $(\mathrm{H})$ and use unskilled-labor-capital combination. This relation justifies why labor $(\mathrm{H})$ enters the production function as a substitute. Finally, including productive land $(\mathrm{R})$ into our production function as a separate (substitute) factor-endowment is needed as the value of land is very sensitive to the changes of economic circumstances in Cyprus. According to PRIO (2006), land prices in the North rose by $417 \%$ in the first half of 2003 , and this upward trend continued till the first quarter of 2006. Firm's production behavior is not purely a technical relationship, since production functions involve not only turning inputs to output but also allocating the resources efficiently in the production process. How those resources are allocated, what determines the level of output that firms supply and what are the costs incurred in the production of goods and services, are determined by the production functions we are using in this model. The usual assumption made in CGE modeling is that, inputs used are strictly complementary and there is no substitution between them, which is captured by the Leontief production function. However, to allow imperfect substitution among the factors of production value added is generated by multiple use of the nested CES production function.Nested CES functions have a wide application in empirical work. Most of the CGE models use 2-level nested approach in production. The example of 3-level nested CES function is seen in literature by Khan and Rafiq (1993). Our 3-level Nested CES production function is divided into 3 subcategories to enable us to consider factor specific elasticity of substitution parameter for each pairs. At the first level (the lowest nest), production function $J_{i}$ represents composite output which is produced using only capital and labor (L). To derive factor demand equations total cost of factor inputs is minimized subject to the composite production function. At the second level (the middle nest), composite input $J_{i}$ and labor $(\mathrm{H})$ enter the nested CES production function as substitute inputs, where production process is shown in Figure 1.

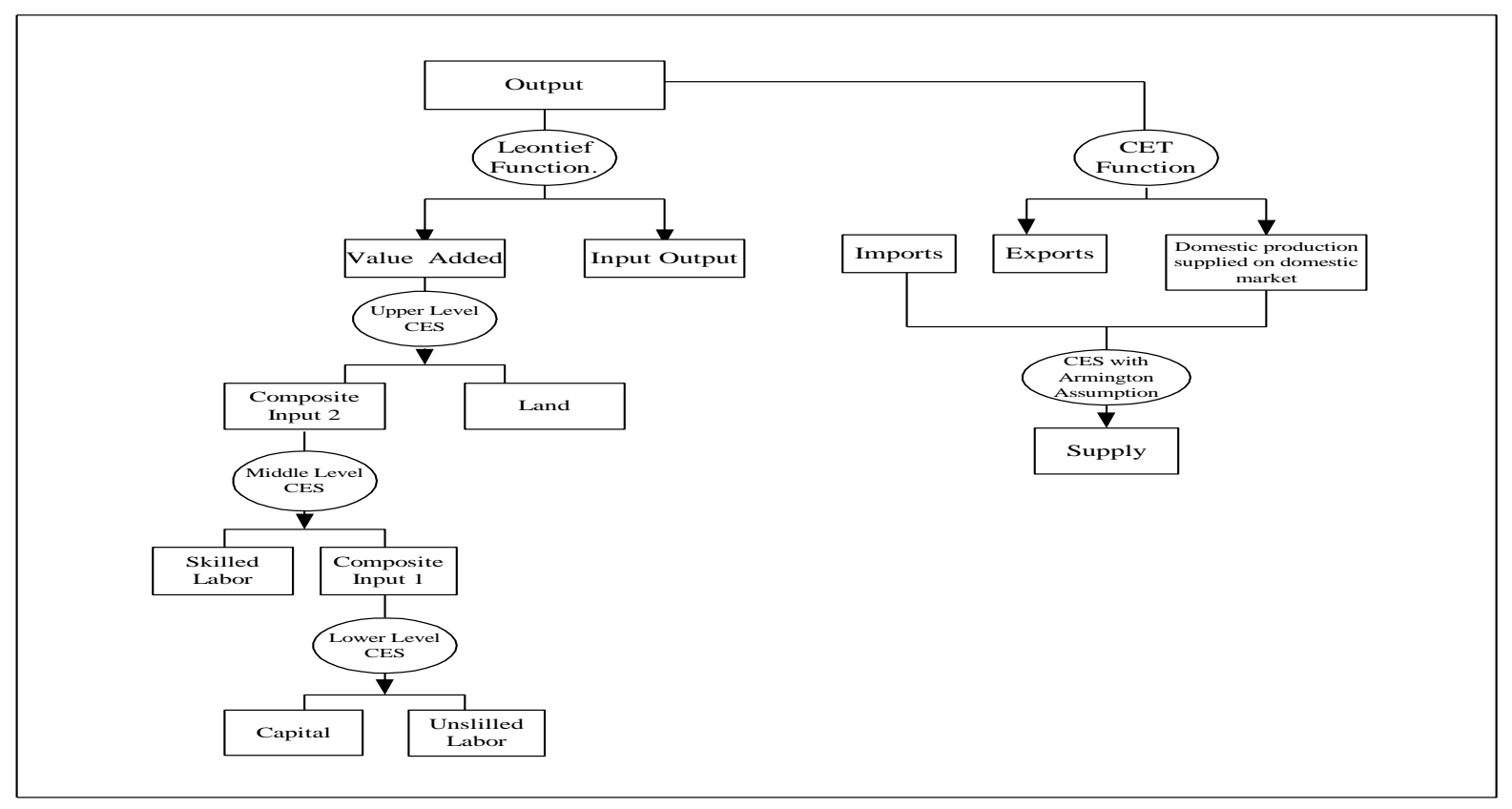

Figure 1: CGE Model - The Market Supply

Finally, value added is formulated through the following upper nest CES function;

$X D_{i}=A_{i}\left\{\delta_{i}\left[\left(\beta_{i}\left[\left(\gamma_{i} K_{i}^{\mu_{i}}+\left(1-\gamma_{i}\right) L_{i}^{\mu_{i}}\right)^{1 / \mu_{i}}\right]^{\rho_{i}}+\left(1-\beta_{i}\right) H_{i}^{\rho_{i}}\right)^{1 / \rho_{i}}\right]^{\theta_{i}}+\left(1-\delta_{i}\right) R_{i}^{\theta_{i}}\right\}^{1 / \theta_{i}} i=1, \ldots, 13$

Factor demand functions derived from optimization are, 


$$
\begin{aligned}
& K_{i}^{*}=\frac{\gamma_{i}^{e_{i}} \cdot k_{i}^{-e_{i}}}{\left(\gamma_{i}^{e_{i}} \cdot k_{i}^{1-e_{i}}+\left(1-\gamma_{i}\right)^{e_{i}} \cdot l_{i}^{1-e_{i}}\right)^{-\left(e_{i} / 1-e_{i}\right)}} \cdot J_{i} \\
& L_{i}^{*}=\frac{\left(1-\gamma_{i}\right)^{e_{i}} \cdot l_{i}^{-e_{i}}}{\left(\gamma_{i}^{e_{i}} \cdot k_{i}^{1-e_{i}}+\left(1-\lambda_{i}\right)^{e_{i}} \cdot l_{i}^{1-e_{i}}\right)^{-\left(e_{i} / 1-e_{i}\right)} \cdot J_{i}} \\
& H_{i}^{*}=\frac{\left(1-\beta_{i}\right)^{s e_{i}} \cdot h_{i}^{-s e_{i}}}{\left(\beta_{i}^{s e_{i}} \cdot j_{i}^{1-s e_{i}}+\left(1-\beta_{i}\right)^{s e_{i}} \cdot h_{i}^{1-s e_{i}}\right)^{-\left(s e_{i} / 1-s e_{i}\right)} \cdot G_{i}} \\
& R_{i}^{*}=\frac{\left(1-\delta_{i}\right)^{g e_{i}} \cdot r_{i}^{-g e_{i}}}{\left(\delta_{i}^{g e_{i}} \cdot g_{i}^{1-g e_{i}}+\left(1-\delta_{i}\right)^{g e_{i}} \cdot r_{i}^{1-g e_{i}}\right)^{-\left(g e_{i} / 1-g e_{i}\right)}} \cdot X D_{i}
\end{aligned}
$$

\subsection{Consumption: Behavior of Households by 2-legged-Nested CES Function}

Preferences of the households are aggregated into two groups; tradable goods and services. These preferences are maximized through CES utility functions. Although a CES function enables us to consider the elasticity of substitution between the commodities it has some limitations especially when commodities have very small shares in total demand. In such cases elasticity of substitution parameter among them would have no effect on their demand when an external impact occurs. To overcome this problem in our study, two separate constrained utility maximizations are conducted and the resulted optimum values of aggregated tradable goods and services are again maximized in an upper level CES utility function.

\subsection{Investment Demand: A Constrained Optimization}

Private and public sectors demand physical capital such as factories, equipment and machinery to make production. They finance their investment purchases from national savings. Therefore, in the model investment demand in each industry is obtained through a constrained optimization of planned investment

\subsection{Public Sector:}

Revenues: Government plays a crucial role in the model, both as a tax collector (direct and indirect) and as a source of demand for consumption and investment goods. The fiscal structure of the public sector is as follows; the public sector collects tax revenue from various sources to finance its purchases, provides services to the society, supplies transfers to private agents and also demands goods and services. Total budget revenue which also represents government sector's income (GTR) consists of tax revenue and other incomes. Tax revenue comes from direct taxes paid by owners of the factors of production and indirect taxes paid by household on their consumption and investments, social security contributions paid by employers and tariffs on traded goods. Other income revenue comes from fund, foreign aid (mainly from Turkey) and a country specific capital income.

Public Expenditures: Public expenditures (total government outlays) consist of current public consumption expenditures plus transfer payments to households. In general, revenues from taxes and various sources determine the expenditures on goods and services and the transfer payments. But in North Cyprus government revenues are dependent on the status of the government expenditures. Government spends on goods and services, conduct investment programs on health, education roads and etc., Then government deficit is mainly financed by Turkey. In reality, there is no evidence to show such a behavior of the public sector but, this is due to the political state of the government in North Cyprus. Public expenditures $C G_{i}$, represented by a Cobb-Douglas type function enter the model as a constraint.

\subsection{International Trade:}

Foreign sector for imported and exported commodities are represented with CES and CET functions where demand for imports and supply of exports are derived through optimization.

\section{Demand for Imported Commodities}

Demand for imported commodities is represented by CES function with Armington assumption to identify traded goods and services in-use, separately. The assumption of homogenous goods is given up by introducing product differentiation through their country of origin on import side, following the Armington assumption. This assumption is widely used in the CGE models to define demands for domestically produced commodities, as well as demand for imported goods when the products are nationally differentiated. Following Lloyd and Zhang 2006, when imports originate in more than origin country, it is assumed that imports from different countries are differentiated from each other and form a group that is separable from the domestically produced products. 
Therefore, it make sense if we assume that, domestically produced and imported inputs used in one industry are imperfect but close substitutes, nested in a production function for the industry group.

With the Armington structure, two-stage budgetary allocation procedure is assumed. Firstly, budget is allocated among the domestically demanded commodities and then expenditure on each commodity is allocated between domestic and imported commodities. In order to derive the demand for domestic and imported commodities, firms try to minimize their total cost subject to their CES type production function.

\section{Supply for Exported Commodities:}

Each industry produces a composite commodity $X D_{i}$ which can be exported and/or sold domestically in the market. Export markets include all regions within the country and international markets.In CGE analysis, exports and domestically sold products are assumed to be differentiated by market (with respect to their prices), with the relationship between them represented by a constant elasticity of transformation (CET) function. CET function describes the market transformation process and each firm allocates its output between the domestic and export markets. Domestic supply function for goods is derived from the first order conditions. Trade balance occurs when exported commodities and imported commodities are equal. In our model, in order to equate the exports to the imported commodities, foreign savings acts as a model closure. Figure 2 represents domestic demand.

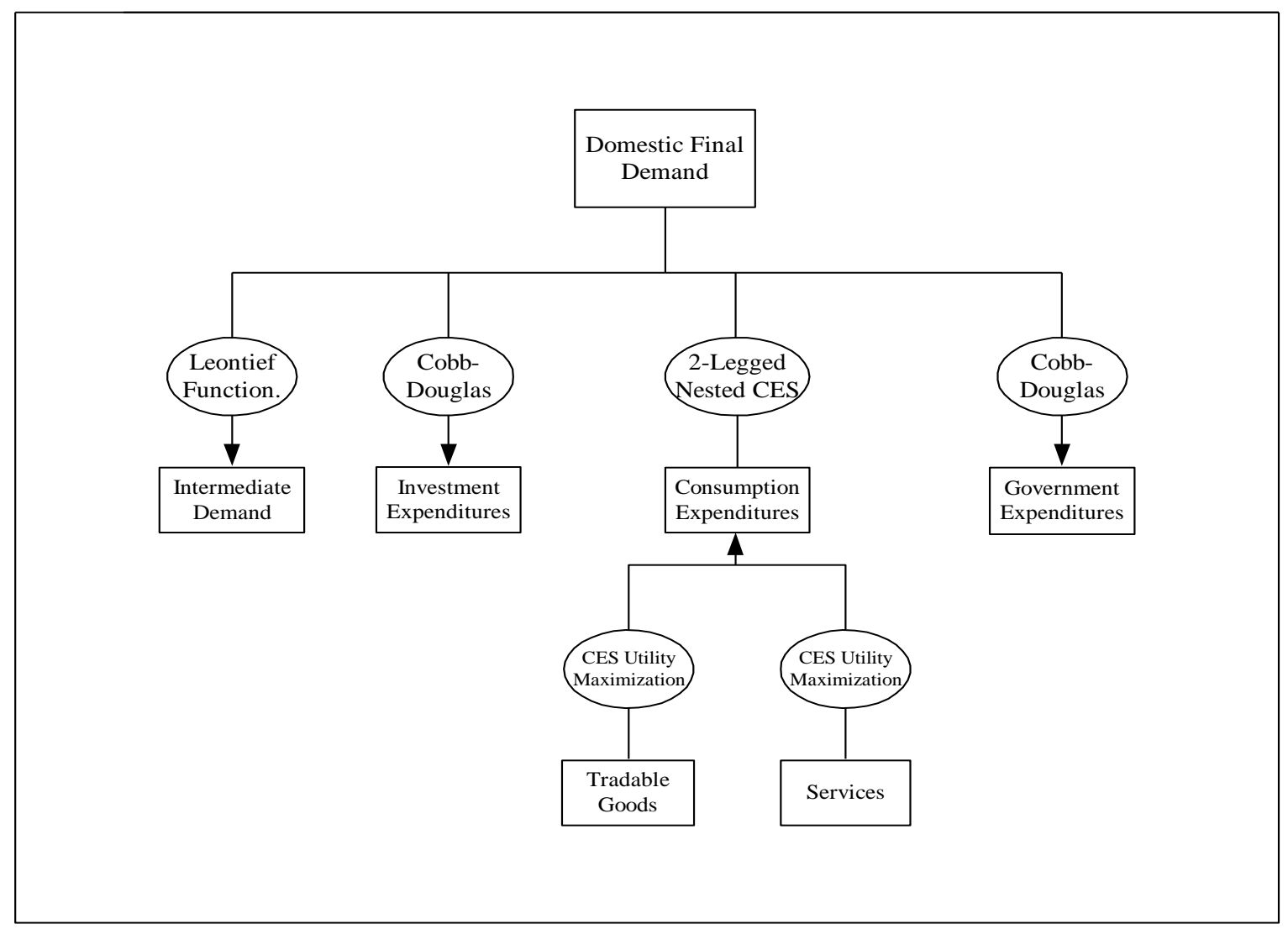

Figure 2: CGE Model-Domestic Final Demand

\section{Simulation Results and Conclusion}

Consistent input-output table is available only for the year 1998 in North Cyprus. The data is aggregated into 13 industries and is used as part of the production process at the intermediate level. However, national accounts data of North Cyprus is widely used to determine the initial public, investment, consumption, export and import expenditures in the model. Direct taxes, foreign savings and transfer payments are also provided from the National Accounts. General Census data for the year 1996 provided detailed information on the number of employed people by literacy within each industry so that we determined the shares of the skilled and un-skilled employment and thus the shares are used to calibrate some of the model variables. There are essentially two kinds of parameters that are needed for the CGE model. These are namely, the distribution parameters and elasticity of substitution parameters. Distribution parameters are calibrated at each stage of the process and elasticity of substitution parameters are taken exogenously from the various resources. After computing all the, the system is validated and the model is run for the benchmark year. System constraints are satisfied through the optimization processes at each sub section. Finally, Walrasian constraints are imposed and homogeneity tests are applied to verify the reliability of the model. 


\section{Simulation \& Results:}

In North Cyprus land use for agricultural production is decreased by $29.89 \%$ between 2004 and 2008 according to the state planning organization of Turkish Republic of Cyprus. However, socio-economic developments and positive impact of Annan plan busted the construction sector and thus increased construction of new buildings and materials used between 2004 and 2008. Some un-used land became available for domestic use for new buildings and some are sold to foreigners. Considering the available information about the recent developments in the North Cyprus economy, it is estimated that supply of land for domestic-use is reduced by 10\%. Furthermore easing the borders between the North and South parts increased the opportunities of finding jobs in the South shifting the number of unskilled labor from North to the South. There is external income in terms of remittances flowing into the North Cyprus economy due to labor mobility and land bought by foreigners. In order to show the impact of this non-factor external income, foreign savings is increased by $18 \%$. Tables below show the combine impact of the external shocks where under flexible exchange rate.

\begin{tabular}{lllc}
\hline & Benchmark & Simulation & \% Change \\
\hline Output & $377,115,512$ & $371,329,851$ & -1.53 \\
Unskilled labor Supply & $29,740,140$ & $26,171,320$ & -12.00 \\
Skilled labor Supply & $72,178,790$ & $72,178,790$ & 0.00 \\
Capital Stock & $110,897,300$ & $110,897,300$ & 0.00 \\
Land \& Resources & $4,575,386$ & $4,117,847$ & -10.00 \\
\hline
\end{tabular}

Table 1: Output and Factor Supply

As shown in Table 1, due to the external income shocks; $12 \%$ reduced unskilled labor, $10 \%$ reduced land and additional income from external resources, output decreased by $1.53 \%$.

\begin{tabular}{llll}
\hline & Benchmark & Simulation & \% Change \\
\hline Investment & $49,779,827$ & $57,361,392$ & 15.23 \\
Stocks & $3,075,951$ & $3,075,951$ & 0.00 \\
Consumption & $188,419,094$ & $186,530,282$ & -1.00 \\
Public Expenditures & $62,884,655$ & $64,958,094$ & 3.30 \\
Imports & $163,766,671$ & $173,464,359$ & 5.92 \\
Import duties & $23,527,821$ & $24,374,692$ & 3.60 \\
Exports & $111,904,224$ & $112,266,641$ & 0.32 \\
Trade Deficit & $51,862,447$ & $61,197,718$ & 18.00 \\
\hline GDP & $\mathbf{2 2 8 , 7 6 9 , 2 5 9}$ & $\mathbf{2 2 6 , 3 5 3 , 3 0 8}$ & $\mathbf{- 1 . 0 6}$ \\
\hline
\end{tabular}

Table 2: GDP \& Trade Performance

As it is indicated in Table 2, GDP decreases by $1.06 \%$ prior to the shocks and trade deficit increased by $18 \%$. Households consumes less and investment expenditures increased by $15.23 \%$. This is due to higher national savings caused by $18 \%$ increase in foreign savings.

\begin{tabular}{llll}
\hline & Benchmark & Simulation & \% Change \\
\hline Unskilled labor Demand & $29,740,140$ & $30,283,359$ & $\mathbf{1 . 8 3}$ \\
Skilled labor Demand & $72,178,790$ & $72,178,783$ & 0.00 \\
Capital Demand & $110,897,300$ & $110,897,300$ & 0.00 \\
Land \& Resources Demand & $4,575,386$ & $2,409,774$ & -47.33 \\
\hline
\end{tabular}

Table 3: Demand for Factors of Production

In Table 3, the impact of the exogenous shock on factor demand is shown. Keeping the wage rates of unskilled workers constant, imposed shocks on land and unskilled labor, increased demand for unskilled labor by $1.83 \%$ but decreased the demand for land and resources by $47.33 \%$. There is no change for demand for skilled labor and capital as their supply is kept exogenously fixed.

\begin{tabular}{llll}
\hline & Bencmark & Simulation & \% Change \\
\hline CPI & 1 & 1.031 & 3.09 \\
Unskilled labor wage & 1 & 1.000 & 0.00 \\
Skilled labor wage & 1 & 1.028 & 2.80 \\
Price of Capital & 1 & 1.020 & 1.97 \\
Price of Land & 1 & 2.088 & 108.84 \\
Exchange Rate & 1 & 1.012 & 1.23 \\
\hline
\end{tabular}

Table 4: CPI and Factor Prices 
Table 4 presents the combine effect of the external shock on factor prices, price index (CPI) and foreign exchange rate. All of the prices are determined in the model and changes in the factor prices are smooth except the sand price. When supply of land decreased by $10 \%$, price of land increased by $108.84 \%$.

\begin{tabular}{llll}
\hline & Bencmark & Simulation & \% Change \\
\hline Factor Income & $228,391,200$ & $233,053,400$ & 2.04 \\
Expenditure & $203,270,500$ & $207,419,900$ & 2.04 \\
National Savings & $49,779,830$ & $62,718,080$ & 25.99 \\
HHs Saving & $24,650,610$ & $25,153,800$ & 2.04 \\
Foreign Saving & $51,862,450$ & $61,197,690$ & 18.00 \\
Public Saving & $-23,657,300$ & $-23,657,300$ & 0.00 \\
Tax Revenue & $50,226,930$ & $52,300,370$ & 4.13 \\
\hline
\end{tabular}

Table 5: Income, Savings, Tax Revenue

Table 5 presents combine effects of the exogenous shocks on national savings, household savings, income, household expenditures and tax revenue. Prior to the shocks income, expenditures and household savings increased by $2.04 \%$ and national savings increased by $25.99 \%$ where investment expenditures are financed by national savings in practice. Finally, government tax revenue is increased by $4.13 \%$.

\begin{tabular}{lcccc} 
& $\begin{array}{c}\text { Unskilled } \\
\text { Labor Demand }\end{array}$ & $\begin{array}{c}\text { Skilled } \\
\text { Labor Demand }\end{array}$ & $\begin{array}{c}\text { Capital } \\
\text { Demand }\end{array}$ & $\begin{array}{c}\text { Land\& } \\
\text { Resources }\end{array}$ \\
\hline 1. Crop Production & -5.59 & -7.91 & -7.23 & -51.34 \\
2. Livestock Production & -4.07 & -6.43 & -5.74 & -50.56 \\
3. Forestry & -1.09 & -3.52 & -2.81 & -49.02 \\
4. Fishing & 0.12 & -2.34 & -1.62 & -48.39 \\
5. Quarrying & 11.18 & 8.45 & 9.25 & -42.69 \\
6. Manufacturing & -12.16 & -14.32 & -13.69 & -54.73 \\
7. Electricity - Water & 0.31 & -2.16 & -1.44 & -48.30 \\
8. Construction & 17.42 & 14.53 & 15.38 & -39.48 \\
9. Wholesale and Retail Trade & 3.71 & 1.16 & 1.91 & -46.54 \\
10. Hotels and Restaurants & 4.64 & 2.07 & 2.82 & -46.06 \\
11.Transport and Communication & -0.24 & -2.69 & -1.97 & -48.58 \\
12. Financial Institutions & 2.82 & 0.29 & 1.03 & -47.00 \\
13. Dwellings Business and & & & & -46.89 \\
Personal \& Public Services & 3.04 & 0.51 & 1.25 & \\
\hline
\end{tabular}

Table 6: Percentage Change in Factor Demand

Table 6 presents the percentage changes in factor demand of unskilled labor, skilled labor, capital and land. Demand for land decreased by $47.33 \%$ on average for all industries. This is due to land supply reduction and $108.8 \%$ jump in price of land. However, demand for all factors (except land) increased for quarrying, construction, wholesale \& retail trade, financial institutions and dwellings as expected. Finally, results show that factor demand for agriculture products and manufacturing production decreased prior to the shocks.

\section{Conclusion}

The study focused on the combined impact of reduction in the domestic use of land in all thirteen industries, labor mobility and created external income in terms of remittances due to labor mobility. The results show that such a reduction in each of the resource sectors decreases real household income. The decrease in the household income causes a drop in the household demand for products and a corresponding decline in output is $1.53 \%$. The reduction in the output puts downward pressure on the demand for primary inputs as shown in Table 6. The results also indicate that reduction in domestic land use causes an increase in the rental rate of land by $108.84 \%$. Since the wage rate is assumed to be flexible for unskilled labor, a reduction in the supply of output particularly in agricultural sectors caused a general decline in the demand for labor in agricultural sectors. Preliminary results also show that GDP negatively affected by the external shock. Trade deficit widened and factor prices increased. In North Cyprus positive expectations on resolution of Cyprus problem busted the economy between 2004 and 2008 , but such development was only temporarily. However, due to scarce clean water supply and global warming agriculture sector production deteriorated and productive use of land decreased in recent years. North Cyprus economy is highly vulnerable to external shocks and due to unrecognized status as a sovereign state, North Cyprus lacks the adequate policies and a mix of policy incentives is desirable that promotes agricultural production and recovers from recession. To conclude, it is worth mentioning that the CGE model is the first model for the North Cyprus economy which shows the distributional impact of external shocks. The study can be used as a tool for policy makers. 


\section{References}

- Cardenete, M. A. and Sancho, F. (2003) An Applied General Equilibrium Model to assess the impact of national tax changes on a regional economy. The Applied Regional Science Conference (ARSC).

- Khan, H. and Ashafaque, H. (1989) The Two-level CES Production Function for the manufacturing sector of Pakistan, The Pakistan Development Review, 28(1), 1-12.

- Lloyd, P. J. and Zhang X. (2006) The Armington Model. Productivity Commission, Australian Government, Staff Working Paper, No: 0602.

- Okkerse, L. ( 2005) Effects of migration: an applied general equilibrium analysis for Belgium. JEL classification: D58,F22,J61.

- PRIO Report 2/2006, "The property regime in a Cyprus statement.

- Ryuzo, S. and Tetsunori, K. (1973) The Production Function and the Theory of Distributive Shares. American Economic Association, 63(3), 484-489.

- Sancho, F. (2009) Calibration of CES functions for real-world multisectoral modeling. Economic Systems Research, 21(1), 45-58.

- Shoven, J. B. and Whalley J. (1984) Applied General- Equilibrium Models of Taxation and International Trade: An Introduction and Survey. Journal of Economic Literature, 22(3), 1007-1051.

- Williams, M. F. (2003) Economic Impact of Increased Mexico-U.S. Labor Mobility: A Computational General Equilibrium Analysis. The International Trade Journal, 17(3), 207-225. 